\title{
TERAPI MEDIK GIZI PADA PASIEN SPACE OCCUPYING LESION SEREBELUM METASTASIS DENGAN MALNUTRISI DAN RISIKO TINGGI SINDROM REFEEDING
}

\author{
Dian Sarah Mutiara ${ }^{1}$, Diyah Eka Andayani ${ }^{2 *}$, Diana Sunardi ${ }^{3}$, Tiara Aninditha ${ }^{4}$ \\ $\mathbf{1 , 2 , 3}$ Departemen Ilmu Gizi, Fakultas Kedokteran Universitas Indonesia, \\ Rumah Sakit Umum Pusat Nasional Dr. Cipto Mangunkusumo, \\ ${ }^{4}$ Departemen Neurologi, Fakultas Kedokteran Universitas Indonesia, \\ Rumah Sakit Umum Pusat Nasional Dr. Cipto Mangunkusumo \\ *corresponding author, kontak: dian_sarah88@yahoo.com
}

\begin{abstract}
Abstrak
Metastasis otak merupakan keganasan terbanyak pada susunan saraf pusat yang dapat menimbulkan penurunan kesadaran, menurunkan asupan nutrisi, meningkatkan risiko malnutrisi serta terjadinya gangguan elektrolit yang dapat meningkatkan risiko terjadinya sindrom refeeding. Laporan kasus ini bertujuan untuk membahas tatalaksana pasien dalam menjaga status nutrisi dan meningkatkan kualitas hidup pada pasien space occupying lesion (SOL) serebelum metastasis dengan risiko sindrom refeeding. Laporan kasus berasal dari pasien rawat inap yaitu perempuan berusia 54 tahun dengan diagnosis hidrosefalus obstruktif ec SOL serebelum suspek metastasis, karsinoma mammae sinistra stadium III T3N3M1 dengan malnutrisi berat, kaheksia kanker, dan risiko tinggi sindrom refeeding. Pasien mengalami kondisi malnutrisi dan terdapat gangguan elektrolit. Pasien mengalami penurunan kesadaran dan membutuhkan jalur nutrisi artifisial. Pasien mendapatkan terapi medik gizi berupa peningkatan nutrisi bertahap dan koreksi elektrolit. Pasien mengalami perbaikan kadar elektrolit. Namun, pasien mengalami efusi pleura masif berulang dan perdarahan saluran cerna sehingga pasien dalam kasus tersebut meninggal.
\end{abstract}

Kata kunci : kaheksia, kanker, malnutrisi, metastasis, sindrom refeeding

\begin{abstract}
Brain metastases are the most common malignancy in the central nervous system that can cause loss of consciousness, low nutrient intake, malnutrition, electrolyte imbalance, and refeeding syndrome. This case report aims to discuss the management of patients in maintaining nutritional status and improving quality of life in a patient with space occupying lesion (SOL) metastases cerebellum with refeeding syndrome risk. Case report: female, 54 years old with diagnosis of obstructive hydrocephalus ec SOL cerebellum suspected metastases, carcinoma mammae stage III T3N3M1 with severe malnutrition, cancer cachexia, and high risk refeeding syndrome. The patient was malnourished and had an electrolyte imbalance. She was unconscious and required artificial feeding. Diet was gradually increased according to her tolerance and electrolytes imbalance were corrected. The patient's electrolyte imbalance has been corrected. However, the patient's died because of her poor clinical condition with recurrent massive pleural effusion and gastrointestinal bleeding.
\end{abstract}

Keywords : cachexia, cancer, malnutrition, metastases, refeeding syndrome

\section{Pendahuluan}

Metastasis otak merupakan bentuk keganasan terbanyak pada susunan saraf pusat yang sering dijumpai dibandingkan dengan tumor otak primer. ${ }^{1}$ Kanker payudara merupakan kanker kedua 
terbanyak (22-25\%) yang mengakibatkan metastasis otak setelah kanker paru (2530\%). Lesi metastasis pada serebrum sebesar $85 \%$ dan serebelum sebesar $15 \% .^{2}$ Pasien dengan metastasis serebelum memiliki prognosis yang buruk karena meningkatkan risiko terjadinya kompresi batang otak yang dapat menimbulkan kematian mendadak. ${ }^{1,3}$

Penyakit kanker berisiko mengalami malnutrisi. ${ }^{4,5}$ Kondisi malnutrisi, kaheksia, dan kanker membutuhkan asupan energi yang lebih tinggi. Penelitian Kapoor N, dkk. ${ }^{6}$ perempuan dengan kanker kahesia paliatif di India menunjukkan bahwa pada kelompok intervensi yang mendapat makanan tambahan sebesar $400 \mathrm{kkal} / \mathrm{hari}$ selama 6 bulan dapat meningkatkan berat badan, menurunkan gejala fatigue dan meningkatkan selera makan sehingga meningkatkan kualitas hidup. Namun, pemberian nutrisi yang tinggi pada pasien dengan riwayat asupan yang rendah dalam jangka waktu lama dapat mengakibatkan gangguan elektrolit dan meningkatkan risiko sindrom refeeding. ${ }^{7}$ Sindrom refeeding adalah pergeseran cairan dan elektrolit yang bersifat fatal dan muncul pada pasien malnutrisi berat yang mendapatkan artificial refeeding (nutrisi enteral atau parenteral) dan atau peningkatan kalori setelah periode asupan kalori yang rendah atau tidak ada asupan kalori. ${ }^{5}$ Salah satu populasi yang berisiko mengalami sindrom refeeding adalah pasien dengan keganasan. ${ }^{8}$ Pasien dengan metastasis otak sering mengalami penurunan kesadaran sehingga membutuhkan nutrisi artifisial baik enteral ataupun parenteral. ${ }^{9,10}$ Salah satu risiko pemberian nutrisi artifisial adalah sindrom refeeding. ${ }^{11}$ Pemberian makanan dapat menginduksi perubahan hormonal dan metabolik sehingga menimbulkan komplikasi klinis. ${ }^{5}$ Sindrom refeeding ditandai dengan pergeseran elektrolit (hipofosfatemia, hypomagnesemia, dan hipokalemia), defisiensi tiamin, kelebihan cairan, dan retensi sodium sehingga terjadi disfungsi dan aritmia jantung. ${ }^{12}$ Beberapa rekomendasi menyarankan untuk pemberian nutrisi secara bertahap dengan memperhatikan kondisi klinis dan memperbaiki gangguan elektrolit. ${ }^{7}$

Laporan kasus ini dibuat untuk membahas mengenai terapi medik gizi pada pasien metastasis SOL serebelum dengan risiko tinggi sindrom refeeding dan diharapkan dapat menambah pengetahuan mengenai tatalaksana nutrisi pada kasus tersebut sehingga dapat mencegah terjadinya sindrom refeeding, menurunkan morbiditas dan mortalitas, serta meningkatkan kualitas hidup pasien. 
Metode

Laporan kasus ini bertujuan untuk membahas tatalaksana nutrisi pada pasien kanker yang mengalami malnutrisi, kaheksia, dan sindrom refeeding. Laporan kasus berasal dari pasien perempuan berusia 54 tahun yang menjalani perawatan di rumah sakit dengan diagnosis penurunan kesadaran, gangguan fungsi luhur, hidrosefalus obstruktif et causa SOL serebelum suspek metastasis, karsinoma mammae sinistra stadium III T3N3M1 (otak, paru, hepar, tulang) post mastektomi dan kemoradiasi, ateletaksis paru sinistra dengan komponen efusi dengan malnutrisi berat, kaheksia, dan risiko tinggi sindrom refeeding. Pasien dikonsulkan ke bagian gizi klinik saat perawatan hari ke-enam dengan masalah asupan dan hipoalbuminemia. Pasien mendapatkan tatalaksana nutrisi yang diberikan oleh dokter spesialis gizi klinik.

\section{Hasil Penelitian}

Pasien kasus di atas masuk perawatan dan dilakukan skrining malnutrisi dengan menggunakan malnutrition screening tools dengan nilai sebesar 5 . Pasien mengalami penurunan kesadaran sejak 1 hari sebelum masuk rumah sakit (SMRS). Pasien terdiagnosis kanker payudara sejak dua tahun SMRS dan menjalani mastektomi dilanjutkan dengan terapi radiasi dan kemoterapi siklus pertama.
Pasien melanjutkan kemoterapi siklus kedua dan mulai sering mengalami mual, muntah, pusing, dan penurunan selera makan serta perubahan konsistensi makanan menjadi makanan lunak. Pasien tampak semakin kurus dan memerlukan bantuan untuk melakukan aktivitas harian. Pasien mengalami penurunan berat badan sebesar $17 \mathrm{~kg}(31 \%)$ dalam 8 bulan terakhir.

Pemeriksaan fisik pasien dijumpai kesadaran apatis, refleks fisiologis menurun, tidak dijumpai kaku kuduk dan refleks patologis, suara redup di lapangan kiri paru dengan rhonki basah kasar di kedua lapangan paru, perut buncit dengan kesan asites, dan dijumpai tanda klinis malnutrisi serta penurunan kapasitas fungsional. Pemeriksaan antropometri dengan indeks massa tubuh $16.4 \mathrm{~kg} / \mathrm{m}^{2}$. Pemeriksaan CTscan otak dengan kontras didapatkan massa solid dengan komponen perdarahan di cerebellum sisi kanan dan kiri dengan edema perifokal. Hidrosefalus obstruktif dengan penyempitan ventrikel IV (gambar 1). Pemeriksaan rontgen thoraks dijumpai efusi pleura kiri masif, suspek efusi pleura kanan dengan kecurigaan metastasis dan pneumonia (gambar 2).

Analisis asupan pasien selama sakit (2 bulan terakhir) mengalami penurunan dengan asupan energi 500 kkal (14 $\mathrm{kkal} / \mathrm{kgBB})$ dan protein 12 gram $(0.3$ 
gram $/ \mathrm{kgBB}$ ). Saat awal perawatan, pasien mendapatkan nutrisi enteral melalui pipa nasogastrik dan nutrisi parenteral dengan total asupan energi sebesar 1600 kkal (43 $\mathrm{kkal} / \mathrm{kgBB})$ dan protein 59 gram (1.6 gram $/ \mathrm{kgBB}$ ). Pasien dikonsulkan ke gizi klinik untuk penanganan kondisi nutrisi pasien. Pasien dilakukan pemerikaan elektrolit dan didapatkan kadar magnesium dan fosfat serum yang rendah. Pasien dicurigai sebagai sindrom refeeding berdasarkan klinis, faktor risiko, dan pemeriksaan laboratorium. Temuan klinis berupa asupan $33 \%$ dari kebutuhan energi total (KET) selama 2 bulan, indeks massa tubuh (IMT) rendah yaitu $16.4 \mathrm{~kg} / \mathrm{m}^{2}$, kehilangan berat badan $17 \mathrm{~kg}(31 \%)$ dalam 2 bulan, serta gangguan elektrolit berupa hipofosfatemia (kadar fosfat $1.7 \mathrm{mg} / \mathrm{dL}$ ) dan hipomagnesemia (kadar magnesium 1.33 $\underline{\mathrm{mg} / \mathrm{dL})}$.

Pemberian nutrisi pasien diturunkan menjadi $600 \mathrm{kkal}(16 \mathrm{kkal} / \mathrm{kgBB})$ dan protein 25 gram $(0.7$ gram $/ \mathrm{kgBB})$ serta dilakukan pemberian tiamin, suplementasi fosfat dan magnesium. Pemberian nutrisi ditingkatkan bertahap hingga 900 kkal (24 $\mathrm{kkal} / \mathrm{kgBB})$ dengan protein 24 gram (1.1 gram $/ \mathrm{kgBB}$ ). Kadar magnesium mengalami perbaikan dan suplementasi magnesium dihentikan. Namun, kadar fosfat belum mengalami perbaikan dan suplementasi fosfat dilanjutkan.

Pasien mengalami perburukan selama perawatan. Pasien mengalami sesak yang memberat dan dilakukan thorakosentesis ulang namun keluhan sesak muncul kembali dan dilakukan pemasangan chest drain. Pasien juga mengeluarkan cairan hitam dari pipa nasogastrik yang kemungkinan disebabkan oleh stress ulcer. Keadaan umum pasien memburuk dan pasien meninggal saat perawatan rumah sakit hari ke-17.

\section{Diskusi}

Pasien didiagnosis kanker payudara sinistra non-specific type grade III T3N3M1 (otak, paru, hepar, tulang). Kanker payudara biasanya akan mengalami metastasis ke tulang, paru, dan otak. ${ }^{2}$ Kanker payudara merupakan penyebab kedua tersering timbulnya metastasis otak setelah kanker paru dan memiliki prognosis yang buruk walaupun telah mendapatkan deteksi dan tatalaksana dini. ${ }^{13}$ Penelitian Oltean, dkk. ${ }^{3}$ menunjukkan insiden metastasis otak pada kanker payudara pada usia antara 45-54 tahun. Pada kasus, pasien perempuan berusia 54 tahun dengan kanker payudara yang mengalami metastasis ke berbagai organ seperti paru, hati, tulang, dan otak. Hasil CT-scan otak kontras pasien 
didapatkan massa solid dengan komponen perdarahan di cerebellum sisi kanan dan kiri dengan edema perifokal disertai dengan hidrosefalus obstruktif dengan penyempitan ventrikel IV

Kanker menginduksi pelepasan sitokin inflamasi sehingga terjadi katabolisme jaringan, kehilangan berat badan, dan anoreksia. ${ }^{14}$ Pasien tersebut mengalami penurunan asupan makan, kehilangan berat badan, dan dijumpai tanda malnutrisi dari pemeriksaan fisik. Pasien didiagnosis sebagai malnutrisi berdasarkan kriteria World Health Organization (WHO) dengan IMT $16.3 \mathrm{~kg} / \mathrm{m}^{2}$ dan berdasarkan kriteria malnutrisi menurut American Society for Parenteral and Enteral Nutrition (ASPEN). Malnutrisi berdasarkan kriteria ASPEN dapat ditegakkan apabila secara klinis dijumpai dua dari enam tanda yaitu asupan energi yang tidak adekuat, penurunan berat badan, penurunan massa otot, penurunan massa lemak subkutan, akumulasi cairan secara lokal atau general, dan penurunan status fungsional. ${ }^{15}$ Pasien memiliki penyakit dasar berupa kanker mammae yang termasuk dalam penyakit kronis. Pasien kasus di atas dijumpai asupan energi $\leq 75 \%$ KET selama $\geq 1$ bulan; penurunan berat badan $>20 \%$ dalam 1 tahun; terdapat penurunan lemak subkutan berupa mata agak cekung, massa lemak pada biseps dan triseps masih terasa namun tidak cukup penuh, sela iga tampak menjauh; terdapat penurunan massa otot berupa pelipis sedikit cekung, klavikula menonjol; serta terdapat penurunan kapasitas fungsional dari indeks barthel dengan nilai nol (ketergantungan total) dan Eastern Cooperative Oncology Group (ECOG) sebesar empat yang berarti pasien tidak mampu beraktivitas dan merawat diri, aktivitas pasien terbatas di tempat tidur atau kursi.

Pasien juga didiganosis kaheksia kanker menurut Cachexia Consensus Conference tahun 2006. Kaheksia merupakan sindrom metabolik kompleks yang berkaitan dengan penyakit dasar dan ditandai dengan kehilangan massa otot dengan atau tanpa kehilangan lemak. Diagnosis kaheksia dapat ditegakkan jika terdapat satu kriteria mayor ditambah dengan tiga dari lima kriteria minor. Kriteria mayor berupa penurunan berat badan 5\% dalam waktu kurang dari 12 bulan atau IMT $<20 \mathrm{~kg} / \mathrm{m}^{2} \cdot{ }^{16,17}$ Kriteria minor antara lain penurunan kekuatan otot, fatigue, anoreksia, indeks massa bebas lemak (massa otot) rendah, dan nilai laboratorium yang abnormal. Penilaian kekuatan otot atau kapasitas fungsional dapat menggunakan skala Karnofsky dan ECOG. Abnormalitas nilai laboratorium dapat dijumpai peningkatan penanda inflamasi (IL-6 >4 
pg/dL, CRP >5 mg/L), anemia ( $\mathrm{Hb}<12$ $\mathrm{g} / \mathrm{dL}), \quad$ hipoalbuminemia $\quad(<3.2 \mathrm{~g} / \mathrm{dL}) .{ }^{16}$ Pasien kasus di atas memiliki penyakit dasar yaitu kanker dan dijumpai adanya penurunan berat badan sebesar $31 \%$ dalam 2 bulan, IMT $16.4 \mathrm{~kg} / \mathrm{m} 2$ serta dijumpai kriteria minor berupa penurunan kekuatan otot dengan nilai ECOG 4, fatigue, dan anoreksia sehingga pasien didiagnosis sebagai kaheksia kanker.

Pasien dengan keganasan berisiko mengalami sindrom refeeding karena starvasi yang panjang dan kehilangan elektrolit. $^{7}$ Kemoterapi mengakibatkan mual, muntah, anoreksia, mukositis, dan diare sehingga meningkatkan kehilangan elektrolit. Radiasi menginduksi toksisitas gastrointestinal dan mukositis serta anoreksia. $^{7}$ Sindrom refeeding adalah pergeseran cairan dan elektrolit yang bersifat fatal yang muncul pada pasien malnutrisi berat yang mendapatkan artificial refeeding dan atau peningkatan kalori setelah periode asupan kalori yang rendah atau tidak ada asupan kalori. ${ }^{5}$ Sindrom refeeding ditandai dengan pergeseran elektrolit yang berat (hipofosfatemia, hipomagnesemia, dan hipokalemia), defisiensi vitamin (tiamin), overload cairan dan retensi sodium sehingga mengakibatkan disfungsi dan aritmia jantung. ${ }^{12}$
Diagnosis kriteria sindrom refeeding menurut ASPEN adalah penurunan baik pada salah satu, dua, ataupun tiga dari kadar serum fosfat, potassium, dan atau magnesium sebanyak 10\%-20\% (sindrom refeeding ringan), $20 \%-30 \%$ (sindrom refeeding sedang), atau $>30 \%$ dan atau disfungsi organ yang muncul karena penurunan kadar elektrolit tersebut dan atau karena defisiensi tiamin (sindrom refeeding berat), serta hal tersebut terjadi dalam 5 hari setelah inisiasi atau peningkatan energi. Gejala yang muncul dapat beragam tergantung dari derajat penurunan kadar elektrolit. $^{7}$ Pasien dengan kadar elektrolit yang rendah sebelum inisiasi nutrisi memerlukan suplementasi agresif. Elektrolit sebaiknya dinormalkan terlebih dahulu sebelum memulai pemberian kalori ataupun peningkatan kalori. ${ }^{7}$

Pasien tersebut memiliki asupan oral yang sangat rendah dalam periode yang panjang (asupan sekitar 33\% KET selama 2 bulan), IMT yang rendah (16.4 kg/m2), kehilangan berat badan $20 \%$ dalam 2 bulan, serta dijumpai gangguan elektrolit berupa hipofosfatemia dan hipomagnesemia. Hal ini perlu diperhatikan kemungkinan terjadinya sindrom refeeding. Pasien dengan keganasan berisiko mengalami sindrom refeeding karena starvasi yang panjang dan kehilangan elektrolit. Kemotarapi mengakibatkan mual, 
muntah, anoreksia, mukositis, dan diare sehingga meningkatkan kehilangan elektrolit. Radiasi menginduksi toksisitas gastrointestinal dan mukositis serta anoreksia.

Tatalaksana risiko sindrom refeeding menurut rekomendasi ASPEN adalah inisiasi nutrisi diberikan 100-150 gram dextrosa atau $10-20 \mathrm{kkal} / \mathrm{kgBB}$ selama 24 jam pertama, kemudian ditingkatkan 33\% dari asupan yang diterima untuk setiap 1-2 hari. ${ }^{7}$ Komposisi makronutrien diberikan 40\%-60\% karbohidrat, 30\%-40\% lemak, dan $15 \%-20 \%$ protein tergantung dari kondisi pasien. ${ }^{12}$ Pasien dengan risiko sindrom refeeding sedang hingga tinggi dengan kadar elektrolit rendah, sebaiknya pemberian inisiasi atau peningkatan nutrisi ditahan terlebih dahulu hingga pemberian suplementasi elektrolit atau elektrolit telah normal kembali. Inisiasi ataupun peningkatan kalori sebaiknya ditunda pada pasien dengan kadar fosfat, potassium, atau magnesium rendah derajat berat hingga elektrolit terkoreksi. Pemberian kalori berupa cairan dextrose intravena dan medikasi dalam cairan dextrosa perlu dipertimbangkan dan perlu diwaspadai pada pasien dengan risiko sindrom refeeding sedang hingga tinggi. Jika pasien mendapatkan dextrosa dalam beberapa hari dari cairan maintanace ataupun medikasi dengan dextrosa dan asimptomatik serta kadar elektrolit stabil maka pemberian kalori dapat ditingkatkan. Jika kadar elektrolit sulit terkoreksi atau cendrung turun selama pemberian nutrisi maka turunkan kalori atau jumlah gram dextrosa sebanyak 50\% dan peningkatan dextrosa atau kalori sebanyak $33 \%$ dari capaian selama 1-2 hari dengan memperhatikan kondisi klinis. Pasien diberikan suplementasi tiamin sebanyak 100 $\mathrm{mg} /$ hari sebelum inisiasi nutrisi, diberikan selama 5-7 hari atau lebih. ${ }^{7}$ Pemberian dosis tinggi tiamin dapat mencapai $200 \mathrm{mg}-300$ mg. Vitamin lain juga perlu disuplementasi hingga mencapai $200 \%$ dari dosis rekomendasi harian dan suplementasi trace element diberikan sebanyak $100 \%$ dari dosis rekomendasi harian. ${ }^{12}$

Pasien tersebut terdiagnosis dengan risiko tinggi refeeding syndrome. Pasien direncanakan mendapat nutrisi sebesar 600 kkal (16 kkal/kgBB/hari), protein 34 gram (0.9 gram $/ \mathrm{kgBB} /$ hari, 23\%), lemak 7 gram (11\%), dan karbohidrat 101 gram (66\%). Kebutuhan karbohidrat diberikan dengan memperhatikan kebutuhan minimal glukosa yaitu 100 gram/hari. ${ }^{18}$ Pasien dapat menerima energi $600 \quad$ kkal (16 $\mathrm{kkal} / \mathrm{kgBB} / \mathrm{hari}$ sehingga rencana ditingkatkan menjadi 800 kkal (20 $\mathrm{kkal} / \mathrm{kgBB} / \mathrm{hari}$ ) atau peningkatan sebanyak $33 \%$. Pasien hanya dapat mencapai asupan 
dengan energi 900 kkal (24 kkal/kgBB) dengan protein 24 gram (1.1 gram $/ \mathrm{kgBB})$. Hal tersebut disebabkan karena pasien mengalami perburukan klinis berupa perdarahan saluran cerna sehingga pemberian nutrisi enteral dihentikan. Pasien juga diberikan vitamin B1 2x50 mg sejak hari pertama perawatan gizi kemudian dosis vitamin B1 ditingkatkan menjadi 2x100 mg. Pemantauan klinis sindrom refeeding pada kasus tersebut memiliki kendala karena pasien mengalami efusi pleura masif, asites, dan edema tungkai yang menyerupai gejala klinis sindrom refeeding.

Masalah elektrolit pada pasien juga perlu diperbaiki untuk membantu memperbaiki kondisi klinis pasien. Fosfat merupakan anion utama intraselular. Kadar fosfat normal sebesar 2.7-4.5 $\mathrm{mg} / \mathrm{dL} .{ }^{19}$ Dosis koreksi fosfat tergantung dari derajat hipofofatemia. Kadar fosfat antara 0.61-0.8 $\mathrm{mmol} / \mathrm{L} \quad(1.89-2.48 \quad \mathrm{mg} / \mathrm{dL}) \quad$ disebut hipofosfatemia ringan, kadar fosfat 0.32-0.6 $\mathrm{mmol} / \mathrm{L} \quad(0.99-1.88 \quad \mathrm{mg} / \mathrm{dL}) \quad$ disebut hipofosfatemia sedang, dan kadar fosfat $<0.32 \mathrm{mmol} / \mathrm{L}(<0.99 \mathrm{mg} / \mathrm{dL})$ disebut hipofosfatemia berat ${ }^{12}$ Hasil pemeriksaan kadar fosfat pada pasien sebesar $1.7 \mathrm{mg} / \mathrm{dL}$ yaitu hipofosfatemia sedang. Pasien mendapatkan suplementasi fosfat dengan potassium dihidrogen phosphate 1 gram/hari. Namun, kadar fosfat tidak mengalami perubahan setelah tiga hari pemberian suplementasi sehingga potassium dihidrogen phosphate ditingkatkan menjadi 2 gram/hari.

Magnesium merupakan kation intraselular terbanyak kedua. Kadar serum magnesium normal adalah 1.5-2.4 mg/dL. Salah satu penyebab terjadinya hipomagnesemia adalah starvasi dan malnutrisi. Koreksi magnesium diberikan melalui oral ataupun intravena. ${ }^{12,19}$ Hasil pemeriksaan kadar magnesium pasien sebesar $1.33 \mathrm{mg} / \mathrm{dL}$ termasuk sebagai hipomagnesemia ringan. Tatalaksana hipomagnesemia ringan dengan pemberian oral 10-15 mmol magnesium klorida atau magnesium sitrat atau magnesium Laspartat. $^{12}$ Pasien mendapatkan koreksi magnesium dengan magnesium klorida 3x200 mg. Kadar magnesium mencapai nilai normal setelah pemberian magnesium klorida selama 3 hari.

\section{Kesimpulan dan Saran}

Pasien kanker berisiko mengalami penurunan asupan dalam jangka waktu panjang sehingga menimbulkan malnutrisi dan kaheksia. Pasien dengan penurunan asupan dalam jangka waktu lama dan mendapat nutrisi artifisial berisiko mengalami sindrom refeeding. Intervensi nutrisi diperlukan pasien untuk menjaga dan 
meningkatkan asupan serta kualitas hidup pasien. Pasien dengan masalah nutrisi perlu dilakukan pemantauan ketat terhadap klinis dan laboratorium. Gangguan elektrolit yang muncul perlu diperbaiki sebelum memulai ataupun ketika melakukan peningkatkan nutrisi. Pemberian nutrisi pada pasien dengan risiko sindrom refeeding disesuaikan dengan kondisi klinis dan ditingkatkan secara bertahap.

\section{Konflik Kepentingan}

Para penulis mendeklarasikan bahwa tidak terdapat konflik kepentingan apapun terkait studi pada naskah ini.

\section{Daftar Singkatan}

ECOG : Eastern Cooperative Oncology

ESPEN : American Society for Parenteral and Enteral Nutrition

SMRS : Sebelum Masuk Rumah Sakit

SOL : Space Occupying Lesion

WHO : World Health Organization

\section{Daftar Pustaka}

1. M. Dabija, V. Dorobăţ, Paiu A. Cerebellar metastases - may surgery play a role in the presence of multiple lesions? Romanian Neurosurgery. 2017;31(2):152-60.

2. American Brain Tumor Association. Metastatic Brain Tumors: American Brain Tumor Association, 2017. Hal. 1-24.

3. Oltean D, Dicu T, Eniu D. Brain metastases secondary to breast cancer: symptoms, prognosis and evolution. Tumori. 2009;95:697-701.

4. Aoyagi T, Terracina KP, Raza A, Matsubara $\mathrm{H}$, Takabe K. Cancer cachexia, mechanism and treatment. World J Gastrointest Oncol 2015;7(4):17-29.
5. Arends J, Bachmann $\mathrm{P}$, Baracos $\mathrm{V}$, Barthelemy N, Bertz H, Bozzetti F, dkk. ESPEN guidelines on nutrition in cancer patients. Clin Nutr. 2016:1-38.

6. Kapoor N, Naufahu J, Tewfik S, Bhatnagar S, Garg R, Tewfik I. A Prospective Randomized Controlled Trial to Study the Impact of a Nutrition-Sensitive Intervention on Adult Women With Cancer Cachexia Undergoing Palliative Care in India. Integr Cancer Ther. 2017;16(1):74-84.

7. Silva JSVd, Seres DS, Sabino K, Adams SC, Berdahl GJ, Citty SW, dkk. ASPEN Consensus Recommendations for Refeeding Syndrome. Clin Nutr. 2020;0(0):1-18.

8. Friedli N, Stanga Z, Crook M, Culkin A, Laviano A, Sobotka L, dkk. Management and prevention of refeeding syndrome in medical inpatients: An evidence-based and consensus-supported algorithm. Nutr. 2018;47:13-20.

9. Singer P, Berger MM, Berghe GVd, Biolo G, Calder P, Forbes A, dkk. ESPEN Guidelines on Parenteral Nutrition: Intensive care. Clin Nutr. 2009;28:387-400.

10. Lochsa H, Allisonb SP, Meierc R, Pirlicha M, Kondrupd J, Schneidere S, dkk. Introductory to the ESPEN Guidelines on Enteral Nutrition: Terminology, Definitions and General Topics. Clin Nutr. 2006;25:180-6.

11. The American Society for Parenteral and Enteral Nutrition. Complications of Enteral Nutrition. Dalam: Boullata J, Carney LN, Guenter P, editors.Dalam: ASPEN Enteral Nutrition Handbook. United States of America: The American Society for Parenteral and Enteral Nutrition; 2010. Hal. 267-308.

12. Aubry E, Friedli N, Schuetz P, Stanga Z. Refeeding syndrome in the frail elderly population: prevention, diagnosis and management. Clin Exp Gastroenterol. 2018;11:255-64.

13. Sim H-W, Morris PG, Patil S, Khasraw M. Brain metastases in breast cancer. Expert Rev Anticancer Ther. 2014;14(2):173-83.

14. Tisdale MJ. Mechanisms of Cancer Cachexia. Physiol Rev 2009;89:381-410.

15. Witjaksono F, Sukmaniah S, Octovia LI. Malnutrisi Dewasa. Dalam: Permadhi I, Octovia LI, editors.Dalam: Buku Ajar 
Diagnosis dan Terapi Medik Penyakit Gizi Utama. Jakarta: Penerbit Universitas Indonesia (UI-Press); 2018. Hal. 69-100.

16. Manikam NRM, Withaksono F, Octovia LI. Kaheksia. Dalam: Permadhi I, Octovia LI, editors.Dalam: Buku Ajar Diagnosis dan Terapi Medik Penyakit Gizi Utama. Jakarta: Penerbit Universitas Indonesia (UI-Press); 2018. Hal. 101-16.

17. Okoshi MP, Romeiro FG, Martinez PF, Jr SAO, Polegato BF, Okoshil K. Cardiac cachexia and muscle wasting: definition, physiopathology, and clinical consequences. Res rep clin cardiol. 2014;5:319-26.

18. Singer P, Blaser AR, Berger MM, Alhazzani W, Calder PC, Casaer MP, dkk. ESPEN guideline on clinical nutrition in the intensive care unit. Clin Nutr. 2019;38:4879.

19. Kraft MD, Btaiche IF, Sacks GS, Kudsk KA. Treatment of electrolyte disorders in adult patients in the intensive care unit. Am J Health-Syst Pharm. 2005;62:1663 - 82. 


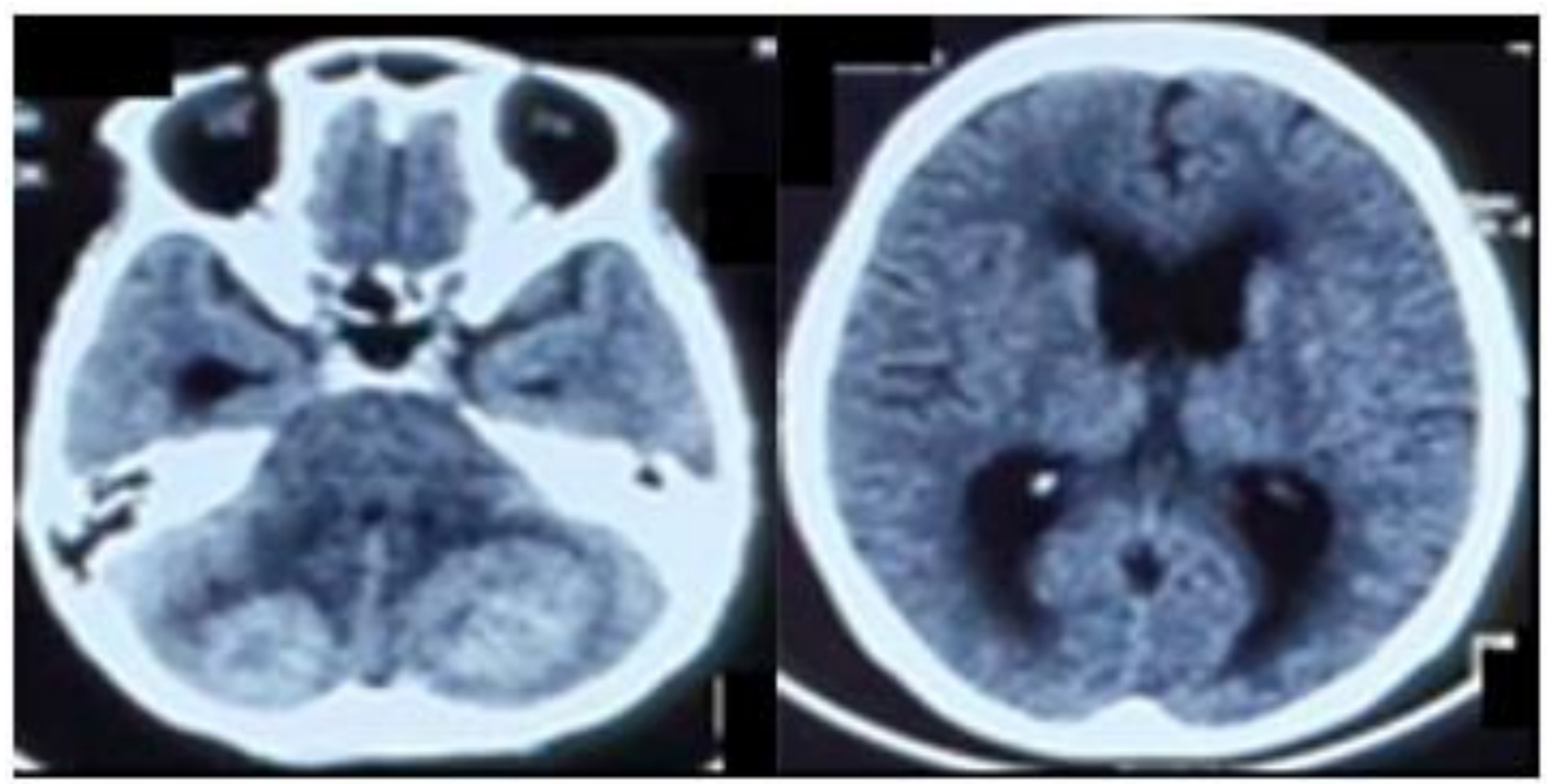

Gambar 1. CT-scan otak dengan kontras.

Terdapat massa solid dengan komponen perdarahan di cerebellum sisi kanan dan kiri dengan edema perifokal. Hidrosefalus obstruktif dengan penyempitan ventrikel IV.
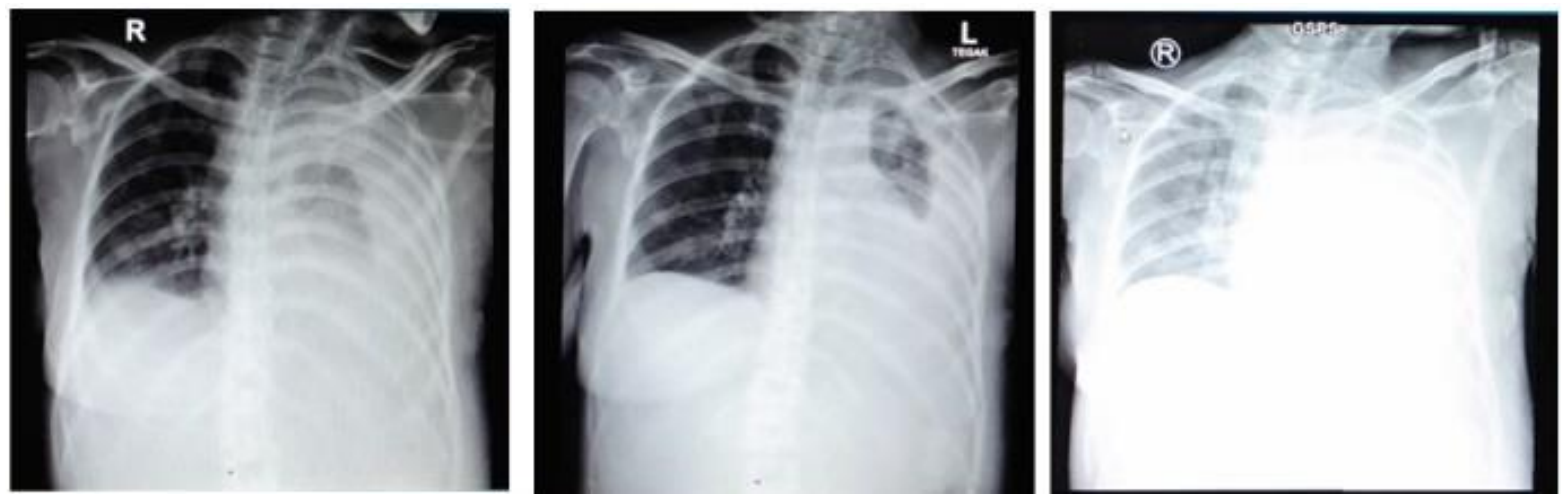

Gambar 2. Rontgen thoraks.

Kiri: Rontgen thoraks hari rawat pertama, terdapat efusi pleura kiri masif, suspek efusi pleura kanan. Tengah: Rontgen thoraks hari rawat pertama setelah thorakosentesis, efusi pleura kiri masif sedikit berkurang. Kanan: Rontgen thoraks hari rawat ke-11, efusi pleura kiri masif dengan komponen ateletaksis 